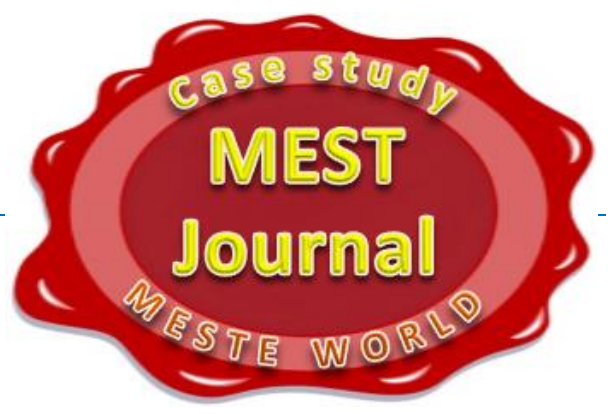

\title{
CONSEQUENCE OF THE FLASH FLOOD IN THE MALA FATRA MOUNTAINS
}

\section{Ladislav Novak}

Faculty of Security Engineering, University of Zilina in Zilina, Zilina, Slovakia

\section{Lubos Mahdon}

Faculty of Security Engineering, University of Zilina in Zilina, Zilina, Slovakia

\section{Jana Lopusanova}

Institute of Continuing Education University of Zilina, Zilina, Zilina, Slovakia

OMESTE

JEL Category: H12, H22, H554, Q54

\begin{abstract}
In 2014 a massive landslide due to extreme rainfall in the Mala Fatra mountains occurred. It caused also consequential damages that indicate typical symptoms of "domino effect" due to extreme weather event. A torrential downpour resulted in flooding that caused an avalanche of rocks, mud, wood and other material which buried parts of Vrátna Dolina and engulfed a lift station to Snilovské Sedlo. Dozens of cars were destroyed as was a road leading from Terchová village to Vrátna Dolina. Vrátna Cottage, road infrastructure and a part of Terchová village were damaged as well. About 200 people present at the area of the natural disaster managed to shelter in nearby buildings and nobody was hurt or killed. Vrátna Dolina resort has a lot to clean up after the disaster. Flood cleanup bill is estimated at tens of millions Euros. Unfortunately, more landslides could follow in the future. The clean-up operations were realized by the integrated rescue system bodies, civil protection, fire and rescue services, municipalities, local governments and other organizations.
\end{abstract}

Keywords: Landslide, flash flood, emergency situation, crisis management

\section{INTRODUCTION}

Nature is more powerful than man. Only a few of us are aware of this truth when enforcing their activities that require entrance into the natural environment and interventions into it. Nature does

The address of the corresponding author: Ladislav Novak

莑=l ladislav.novak@fbi.uniza.sk not matter whether our interventions are motivated by exploring nature, sport activities or our drive for profit. Underestimation of natural hazards and their impacts on human activities lead almost always, sooner or later, to a lesser or greater extent, into incidents caused by the activation of the aforementioned risks. Extreme rain or snowfall, storms, landslides, floods and flash floods and earthquakes repeatedly show us how pointless our interventions in nature are and how 
we do underestimate the natural influences. Often we not even learn from the historical natural disasters. (Dvorak 2010)

\section{CENT-YEAR'S FLOOD IN THE VALLEY VRÁTNA DOLINA AND ITS CONSEQUENCES}

The Valley Vrátna dolina is one of the most beautiful parts of Mala Fatra mountains and the whole Slovakia. Annually thousands of tourists, skiers, drivers and other visitors visit the valley.
The valley is only accessible to motorists through rocky gorges Tiesñavy, where the narrowest point is only less than ten meters in width there. Further above the valley widely branches off up to the main ridge of the Mala Fatra, which is surrounded by the upper basin of the river flow Varínka. In the valley, there are plenty of mountain transport systems and extensive hiking and skiing infrastructure. At the end of the valley there is a cottage Vrátna and a passenger ropeway up to Snilovské sedlo. The village Terchová spreads just below the gorges Tiesňavy (Fig. 1).

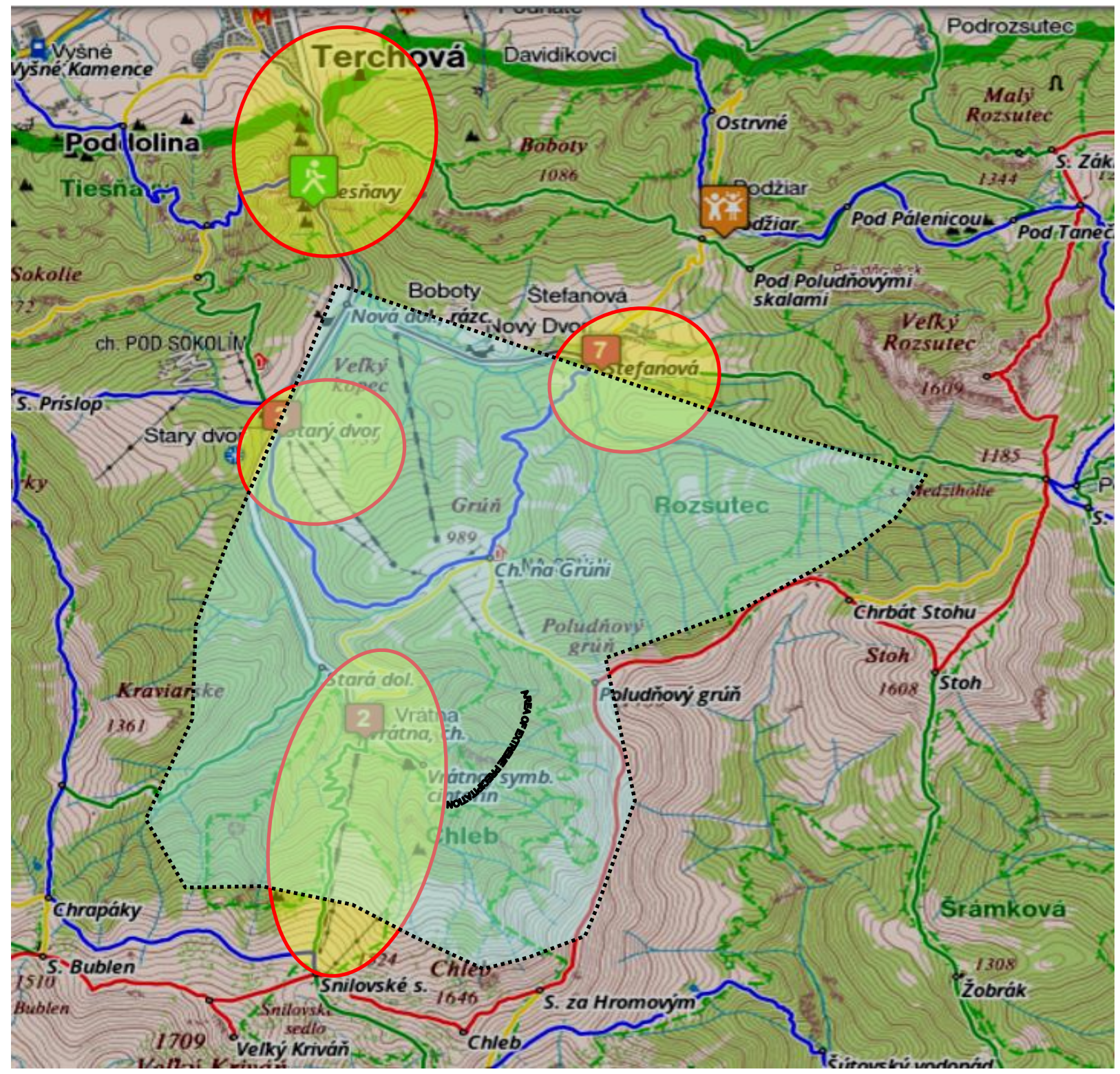

Fig. 1 Geography, topography and location of the natural disaster in the valley Vrátna dolina on July, 21, 2014 
In the valley Vrátna dolina heavy snow and rainfall occur regularly. The extreme situation occurred for example on June, 11, 1848 when during millennial floods fourteen residents in the village lost their lives and the water level reached Tiesñavy level that is shown in a symbolic chapel in the rock above the river Varínka.

Meteorological and hydrological conditions in daylight hours on July, 21, 2014 apparently did not reach the values from that millennial flood, but the consequences of both were almost similar with catastrophic results. They were characterized by converging currents and high air humidity and unstable stratification of the atmosphere.

As a result, in the afternoon above western Slovakia a strong and well-developed line of intensive and relatively slow-moving storms from west to east with some deviations towards south or north was created. These storms arose mainly over the massifs of Mala Fatra and continued moving further east (web geology 2014).

At three o'clock p. m. there was a very severe storm accompanied by strong winds in the town of Žilina as well. It took approximately 30 minutes and reached an intensity of more than $80 \mathrm{~mm} / \mathrm{h}$ (web SHMU 2014).

Around 3.15 p. m. the first storm in Kriván part of Mala Fatra developed and just after 4 p. m. it was followed a second storm, whereas the intensity of rain gradually increased and its value exceeded 50 $\mathrm{mm} / \mathrm{h}$. In the first wave of rainfall (between 3.15 and 3.55 p. m.) about $40 \mathrm{~mm}$ dropped, in the second wave (between 3.55 and 4.55 p. m.), about $50 \mathrm{~mm}$ of precipitation, which means in 1 hour 40 minutes about $90 \mathrm{~mm}$. It is not excluded that in the hills surrounding the valley Vrátna dolina during the storm more than $90 \mathrm{~mm}$ of rain fell (web SHMU 2014).

According to a survey of the working group of the State Geological Institute of Dionýz Štúr the worst situation was created in fan-shaped glacier peaks Chleb, Steny and Hromové whose erosion-formed valleys converge above the cottage Vrátna with the base terminal of the lift.

At the height of 1500 - 1600 meters above sea level moraine sediments and stone rubble were floated and they together with the vegetation formed rocky
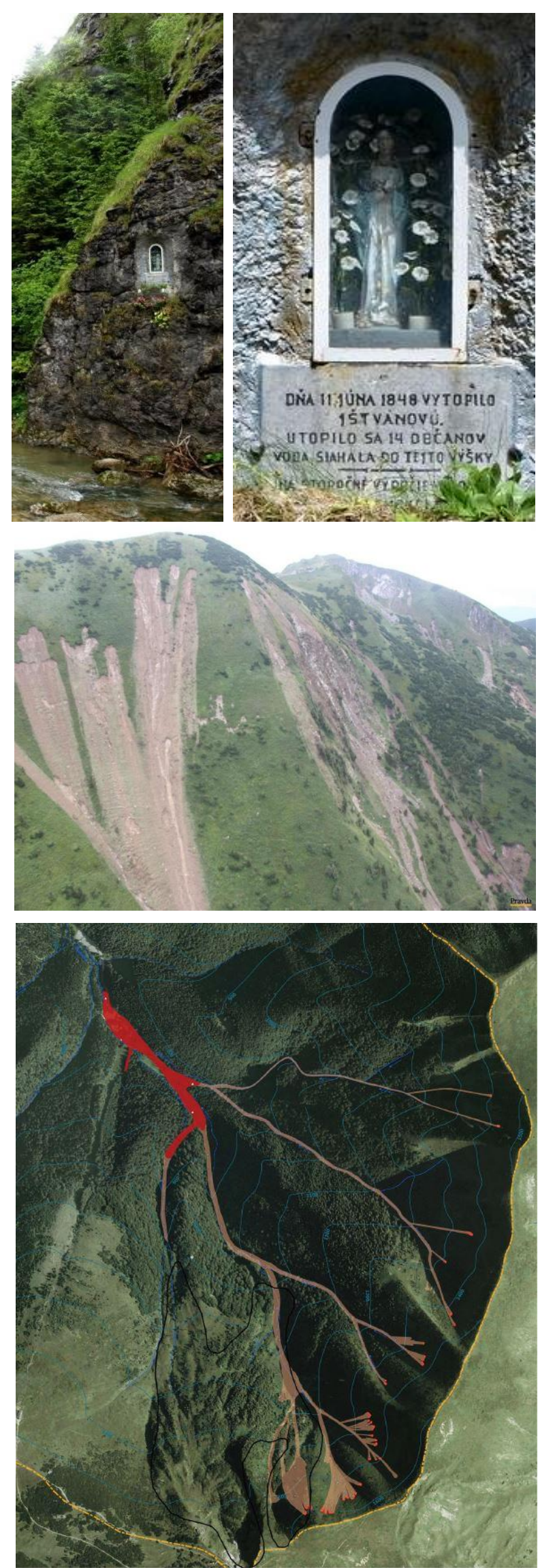
and muddy streams - "mury" - of a thickness of 1-2 meters. Landslides were conditioned by the favourable inclination of the bedrock together with the wetted plant cover. As a result, many relatively small "plates" of slide material broke (each of which reached the size of several $100 \mathrm{~m} 2$ ) and moved particularly through avalanche gutters at the rate of 10 to $20 \mathrm{~m} / \mathrm{sec}$ (web geology 2014).

Approximately 800 meters above the cottage Vrátna individual flows "mury" started to meet. The stream continued through a narrow valley, and took with itself other bottom sediments that had been accumulated there in the previous period and other small streams from side valleys were affixing it up to the point when a mixture of rocks, mud and trees reached thickness of about 2 meters. Most streams eroded valleys down to bedrock (web geology 2014).

At a distance of about 560 meters far from the lift station two main streams combined (funnel connection of valleys). In these parts of the territory stone collapses such as rock fragments and blocks falling down were likely to occur. The overall cubage of the conveyed material was estimated by a working group of the Geological Institute at least $100000 \mathrm{~m}^{3}$.

The front part of rocky and muddy stream flow reached the cottage Vrátna with the base station of the lift, in which, although there was extensive material damage, there was no serious damage to buildings and static lift columns. According to the testimony of those present the rocky flash flood was stacked gradually, so it did not come to a single impact of the front part of the stream directly into the building with the lift - otherwise there would undoubtedly have come to a total destruction of buildings and other infrastructure there.
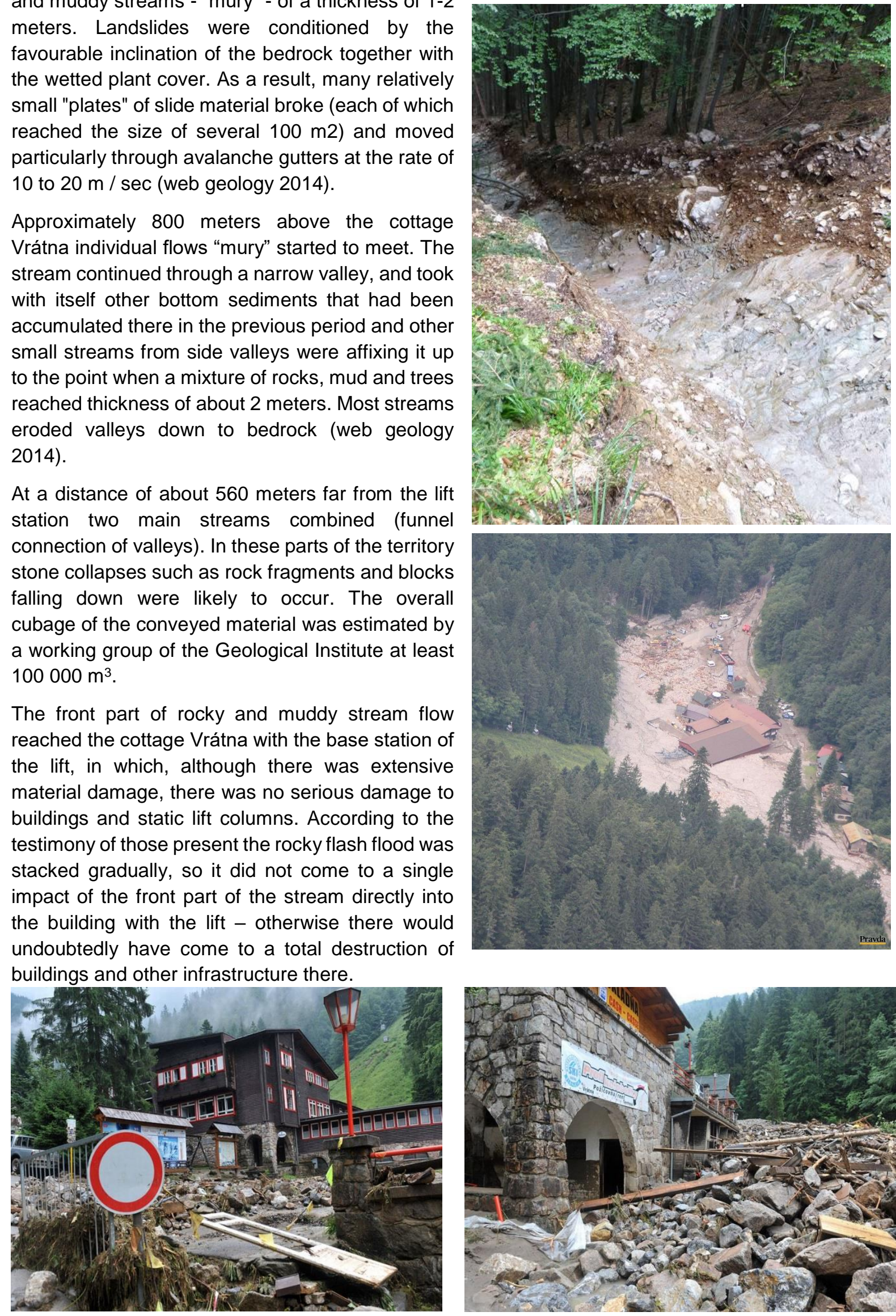

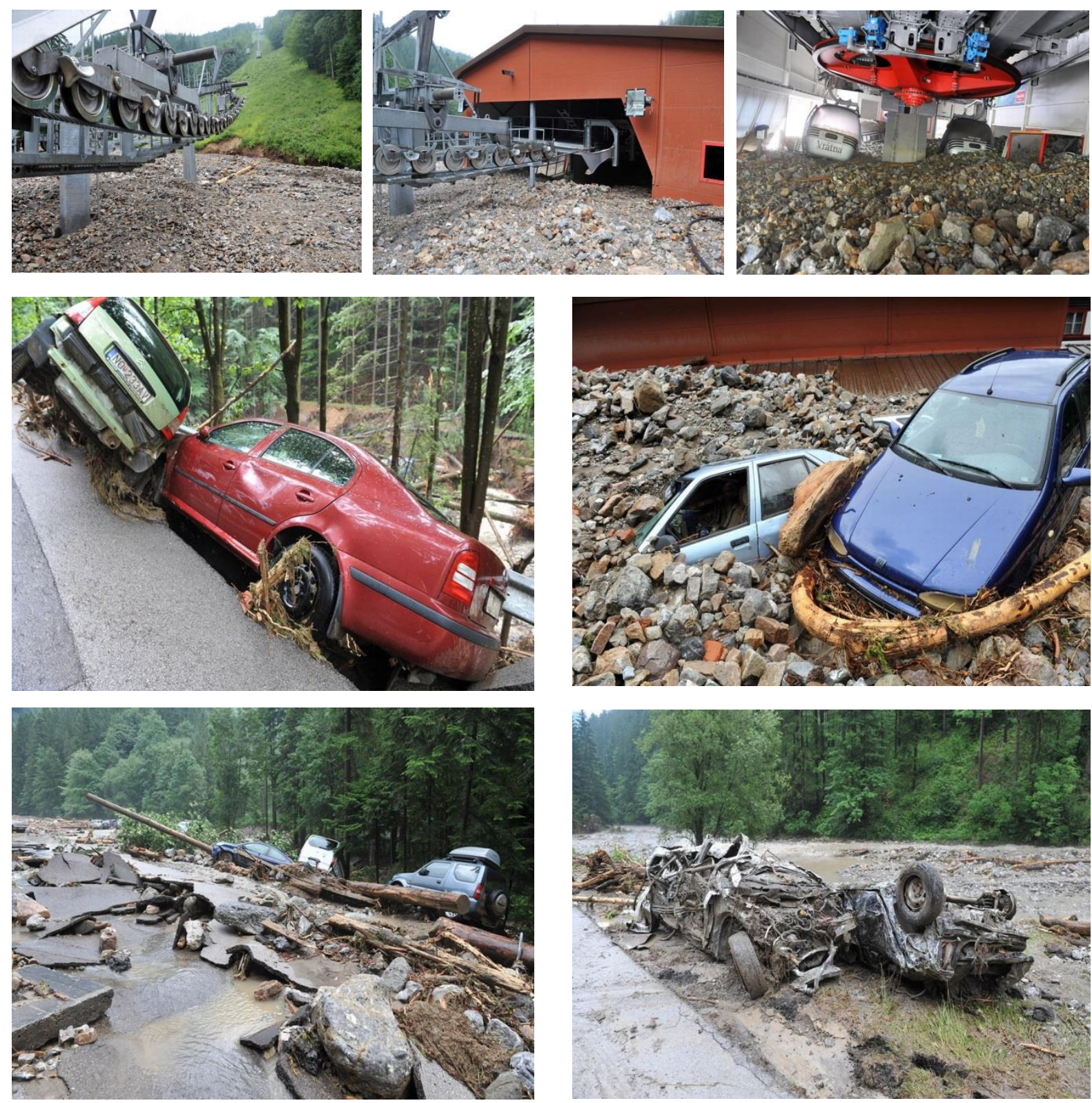

Fig. 2 Photos of landslides effects

Source: Youtube

Fortunately, it seems that the body of the streams due to its morphology (wedge-shaped extension, uneven surface flow) had the potential to absorb, or dampen any further remaining rocky - muddy streams (web geology 2014).

The stream flow broke into the cottage and the building with cable cars and totally devastated the interior up to the second floor. In the cottage at that time, there were approximately sixty people, including children, in there who managed to escape to the upper floors. In case of a total destruction of the buildings in the area their chances would have been unpredictable.
Further stream course was incredibly devastating. On the terrain breakage under the cottage it gained speed, swept away vehicles from the parking lots, destroyed and took with itself an asphalt road in the length of several kilometres, whereas in wider areas it stored drifting natural material, vehicles, cottage furnishings. Just having observed the position of those damaged vehicles one can estimate the stream's height and strength. See pictures from (Youtube 2014 A, Youtube 2014 B, \& Youtube 2014 C)

The stream gradually took on additional side streams, destroyed a part of the ski resort 
infrastructure in the local part called Starý dvor and then it reached the part Tiesňavy. In the narrowest part the stream reached the height of about five metres, it washed the original rock bed by about one metre and scoured the only access road in length of about two-hundred metres as well. In some places it also demolished retaining walls. After its intrusion to the village Terchová it spilled over and flooded the village land, basements and some houses as well. The mainstream stayed in the original, modified riverbed and demolished several local bridges and partially destroyed stone trough lining.

Paradoxically, in the neighbouring valley with the local district Štefanová (under Vel'ký Rozsutec), remote 2 kilometres far from the cottage Vrátna, there was only a little damage and what is more in the famous tourist resort called "Diery", $1 \mathrm{~km}$ away, the local brook level was only slightly increased there.

To deal with a natural disaster the mayor of Terchová announced "emergency situations" and activated all the available material means and resources of local businesses. Components of Fire Department (HZZ), Mountain Rescue (HZS), Military forces of the Slovak Republic (SR OS) and other entities also participated in rescue operations on-site. The total damage amounted to 10 million euros. Consequential damages that arose and still arise to operators of tourist facilities and secondarily to the village/region itself, cannot yet be quantified. The government provided onetime financial assistance to the municipality and the Self Governing Region Žilina for elimination of negative consequences in a total value of 3.6 million euros. In the direct connection with the natural disaster no loss of life occurred.

\section{LESSONS}

AND RECOMMENDATIONS OF THE GEOLOGISTS

- Disastrous rocky and muddy avalanche that originated on July 21, 2014 represents in terms of socio-economic significance (Safarik, 2015) R4 category - very high risk (including expected losses of victims and injuries, serious damage to buildings and infrastructure, the destruction of the existing state of the environment and socio-economic activities).

- Decisive conditions for the creation of catastrophic flash flood in the area there were favourable geological and geomorphological conditions (presence of marl in the jointing area with layers / schistosity in conformity with the slope, a large catchment area converging into the funnel above the lower lift station). For immediate launcher we consider extreme rainfall.

- An important finding is the fact that the slopes in their upper parts (jointing area) of the mountains Mala Fatra are saturated and loosen - in case of extreme rainfall the situation could repeat.

- It is recommended to update the geological map at a scale 1:10,000 in the area of interest. Such a map is essential for drawing up maps of hazard.

- Due to the difficulty of the terrain and partially impassable ground it is recommended to perform air photogrammetry or aerial laser scanning in the affected area.

Lessons for further human (anthropogenic) activities and crisis management:

- The natural disaster could not have been prevented; it did not originate in direct relation to human activities. Only remotely it is possible to seek some connections with the global warming and increase of the intensity of meteorological and hydrological phenomena.

- In order to identify similar phenomena, it is inevitable to carry out a risk analysis based on expertise (in this case, meteorological, hydrological and geological assessments). In case of an identified potential of natural disasters and their consequences, no-one would consider any construction activity in that area.

- Do not allow construction in areas where there is high probability of similar disasters. Utilize the power of insurance companies, which would announce the impossibility of property insurance in vulnerable locations.

Due to the fact that there are hundreds of similar risky areas in Slovakia, it would be necessary to carry out their new risk analysis and take effective preventive measures to 
reduce the potential consequences of similar disasters.

- Strengthen the role of crisis management in the building proceeding with the task to highlight the risks associated with the implementation and operation of buildings.

- Strengthen educational process of the management staff in the areas of risk analysis and identification of potential emergencies and crisis events at all levels of government bodies.

- Develop detailed risk maps and computer programs to simulate the course of similar natural disasters and their consequences.

- Create rescue units of the Integrated Rescue System (IZS) and equip them with the technology in relation to potential emergencies and crisis phenomena in their areas of competence.

\section{CONCLUSION}

The above described natural disaster and its consequences are a great lesson and a memento to human activities and the construction of transport, tourist and industrial infrastructure, not only in the area of Mala Fatra, but the whole Slovakia as well. Only a detailed and specific risk analysis may serve to argue about the inappropriateness of placing buildings in areas of risk, or the implementation of preventive measures in existing buildings. They can also serve to argue the necessity of creating professional rescue teams and their equipment.

\section{WORKS CITED}

Dvořák, Z., Leitner, B., Sventeková, E. Soušek, R. (2010): Risk management in railway transport, $1^{\text {st }}$ edition Pardubice: Institut Jana Pernera, 283 s. ISBN 978-80-86530-71-0

Šafařík, Z., Vičar, D., Losek, V., Rak, J., Trojan, J (2015).: Management of Population Protection against Floods. International Business Information Management Conference (25th IBIMA) on 7 - 8 May 2015 in Amsterdam, Netherlands. ISBN: 978-0-9860419-4-5.

Web SHMU, 2014 http://www.shmu.sk/sk/?page=2049\&id=542.

Web geology 2014 http://www.geology.sk/new/sites/default/files/media/Aktuality/Vratna_dolina_2014/Vratna_ informat\%C3\%ADvna_sprava_web.pdf.

Youtube 2014 A https://www.youtube.com/watch?v=DNEpBLxvs4o\&list=PLxRUrlSre5nGduQw7Rg9TRDOxxME 6m580\&index=4.

Youtube $2014 \quad$ B https://www.youtube.com/watch?v=0kEZMrWfhTI\&index=8\&list=PLxRUrISre5nGduQw7 Rg9TRDOxxME6m580.

Youtube 2014 C https://www.youtube.com/watch?v=AbdVyZ2pe2Y\&list=PLxRUrISre5nGduQw7Rg9TR DOxxME6m580\&index=15.

This paper was supported by projects

APVV 0471-10 Critical infrastructure protection in sector transport and

Centre of excellence for systems and services of intelligent transport II - ITMS 26220120050, project is co-financed by the European Regional Development Fund.

Received for publication: $\quad 26.02 .2016$

Revision received:

14.05 .2016

Accepted for publication: $\quad 10.03 .2016$ 


\section{How to cite this article?}

Style - APA Sixth Edition:

Novak, L., Mahdon, L., \& Lopusanova, J. (2016, July 15). Consequence of the flash flood in the Mala Fatra mountains. (Z. Čekerevac, Ed.) MEST Journal, 4(2), 120-137. doi:10.12709/mest.04.04.02.14

Style - Chicago Sixteenth Edition:

Novak, Ladislav, Lubos Mahdon, and Jana Lopusanova. 2016. "Consequence of the flash flood in the Mala Fatra mountains." Edited by Zoran Čekerevac. MEST Journal (MESTE) 4 (2): 120-137. doi:10.12709/mest.04.04.02.14.

Style - GOST Name Sort:

Novak Ladislav, Mahdon Lubos and Lopusanova Jana Consequence of the flash flood in the Mala Fatra mountains [Journal] // MEST Journal / ed. Čekerevac Zoran. - Belgrade : MESTE, July 15, 2016. 2 : Vol. 4. - pp. $120-137$

Style - Harvard Anglia:

Novak, L., Mahdon, L. \& Lopusanova, J., 2016. Consequence of the flash flood in the Mala Fatra mountains. MEST Journal, 15 July, 4(2), pp. 120-137.

Style - ISO 690 Numerical Reference:

Consequence of the flash flood in the Mala Fatra mountains. Novak, Ladislav, Mahdon, Lubos and Lopusanova, Jana. [ed.] Zoran Čekerevac. 2, Belgrade : MESTE, July 15, 2016, MEST Journal, Vol. 4, pp. 120-137. 